Chapter 8

\title{
High-Performance Alkali-Activated Cement Concretes for Marine Engineering Applications
}

\author{
Pavel V. Krivenko, Hai Lin Cao, Lu Qian Weng and \\ Oleg N. Petropavlovskii
}

Additional information is available at the end of the chapter

http://dx.doi.org/10.5772/64525

\begin{abstract}
The contribution covers results of studies on the alkali-activated cement concretes intended for marine engineering applications. Such properties as strength, wear, corrosion, freeze-thaw, weather resistance and many others have been studied, and the results are reported and discussed in detail. The obtained results suggested to draw a conclusion on high potential of the alkali-activated cement concretes for marine engineering applications, since in their performance properties these concretes are highly advantageous over other concretes used as marine concretes and big savings can be expected in the future due to the longer span of service life. The results are supported by long-term observations in real conditions. The above advantages are attributed to more perfect micro- and macrostructure of the alkali-activated cement stone. The authors have summarized their own experience and results collected by PhD and DSc students under their supervision dedicated to assessment of durability of these concretes, in particular, for marine engineering applications. In order to bring these advanced materials into practice of construction worldwide, two rilem (International Union of Laboratories and Experts in Construction Materials, Systems and Structures) committees have been founded: "Alkali-activated Materials" (2010-2013) and "Durability Testing of Alkali Activated Materials" (2013-ongoing).
\end{abstract}

Keywords: alkaline activation, cement, concrete, marine engineering

\section{Introduction}

Marine concretes are used for making concrete structures that are permanently or from time to time immersed in sea water. In accordance with service conditions in sea water, these marine 
concretes are classified into those that work under water, above water and concretes for zones of alternate level of sea water.

The requirements for marine concrete structures vary depending upon location (zone) of service of the concrete in structures (Table 1) [1, 2].

\begin{tabular}{|c|c|c|c|c|c|c|c|c|c|}
\hline \multirow{4}{*}{$\begin{array}{l}\text { Requirements for } \\
\text { concretes }\end{array}$} & \multicolumn{6}{|c|}{ Massive structures } & \multicolumn{3}{|c|}{ Non-massive structures } \\
\hline & \multicolumn{3}{|c|}{ Outer zone } & \multicolumn{6}{|c|}{ Inner zone } \\
\hline & \multicolumn{9}{|c|}{ Zones relatively water level } \\
\hline & $\begin{array}{l}\text { Under } \\
\text { water }\end{array}$ & $\begin{array}{l}\text { Alternating } \\
\text { level of sea } \\
\text { water }\end{array}$ & $\begin{array}{l}\text { Above } \\
\text { water }\end{array}$ & $\begin{array}{l}\text { Under } \\
\text { water }\end{array}$ & $\begin{array}{l}\text { Alternating } \\
\text { level of sea } \\
\text { water }\end{array}$ & $\begin{array}{l}\text { Above } \\
\text { water }\end{array}$ & $\begin{array}{l}\text { Under } \\
\text { water }\end{array}$ & $\begin{array}{l}\text { Alternating } \\
\text { level of sea } \\
\text { water }\end{array}$ & $\begin{array}{l}\text { Above } \\
\text { water }\end{array}$ \\
\hline Water resistance & + & + & + & + & + & - & + & + & + \\
\hline $\begin{array}{l}\text { Water } \\
\text { impermeability }\end{array}$ & + & + & + & + & + & - & + & + & + \\
\hline $\begin{array}{l}\text { Freeze-thaw } \\
\text { resistance }\end{array}$ & - & + & + & - & - & - & - & + & + \\
\hline $\begin{array}{l}\text { Low heat of } \\
\text { hydration }\end{array}$ & + & + & + & + & + & + & - & - & - \\
\hline Weather resistance & - & + & + & - & + & + & - & + & + \\
\hline $\begin{array}{l}\text { Corrosion } \\
\text { resistance }\end{array}$ & + & + & + & + & + & + & + & + & + \\
\hline $\begin{array}{l}\text { Abrasion } \\
\text { resistance }\end{array}$ & + & + & - & + & + & - & + & + & - \\
\hline
\end{tabular}

Table 1. Requirements for marine concretes vs. service conditions.

Especially, strict requirements are applied to marine concretes working in the zone of alternating sea level and the "above water" zone of the outer sides of the marine concrete structures.

Compressive and flexural strength at the age of 28 or 60 or 180 days are main characteristics of concretes intended for contemporary marine structures. Usually, concretes with compressive strength of 40-50 MPa are used as marine concretes.

Among the most important characteristics of marine concretes which determine durability are: freeze-thaw resistance, water permeability, resistance to corrosive exposure of sea water (marine environment), weather resistance, protective properties of concrete with regard to corrosion of reinforcement, abrasion resistance, etc.

As a rule, these requirements are met through a proper concrete mix design and by taking measures on protection of concrete and reinforcement in order to guarantee service life reaching 50 years. 
On the other hand, one of the main criteria of global sustainable development concept is an issue of durability (lifespan of concrete over 100 years).

Existing widely used cements due to a four-phase principle of compositional build-up and hydration product phase composition are not able to guarantee such durability of concretes.

That is why the only way to proceed is to use alternative cements. The alkali-activated cements represent one of such alternatives (Table 2) [3, 4].

\begin{tabular}{llll}
\hline Cement type & Early strength & Durability & Chemical resistance \\
\hline Portland cement & ++ & ++ & + \\
Blended cement & + & +++ & ++ \\
High alumina cement & +++ & + & +++ \\
High sulphate cement & + & ++ & +++ \\
Sulphoaluminate cement & +++ & ++ & +++ \\
Alkali activated cement & +++ & +++ & +++ \\
\hline
\end{tabular}

Note: (+) low, (++) medium, (+++) high.

Table 2. Comparative properties of various cements.

High efficiency of the alkali-activated cement concretes is proved by a vast experience collected from over 50-year use in structures for marine engineering, hydro-engineering, road and agricultural construction as well as residential, industrial, public buildings all over the world [5].

\section{General information on alkali-activated cements}

As long ago as in 1957, Viktor Glukhovsky, a scientist from Kiev (USSR, Ukraine), has discovered that compounds of alkali metals ( $\mathrm{Li}, \mathrm{Na}, \mathrm{K}, \mathrm{Rb}, \mathrm{Cs}$ ), the elements of the first group of the Periodic Table, could exhibit hydraulic binding properties similar to those of alkali earth metals $(\mathrm{Mg}, \mathrm{Ca}, \mathrm{Sr}, \mathrm{Ba})$, the elements of the second group [3].

As a result, an idea of creation of cementitious materials has been transformed as the following:

“Old scheme" (portland cement, high-alumina cement)

$$
\left.\begin{array}{l}
\mathrm{CaO}-\mathrm{SiO}_{2} \\
\mathrm{CaO}-\mathrm{Al}_{2} \mathrm{O}_{3}
\end{array}\right\}+\mathrm{H}_{2} \mathrm{O} \rightarrow \begin{gathered}
\mathrm{CaO}-\mathrm{SiO}_{2}-\mathrm{H}_{2} \mathrm{O} \\
\mathrm{CaO}-\mathrm{Al}_{2} \mathrm{O}_{3}-\mathrm{H}_{2} \mathrm{O}
\end{gathered}
$$

"New scheme" (alkali-activated cement) (AAC) 


$$
\left.\begin{array}{l}
\mathrm{Al}_{2} \mathrm{O}_{3}-\mathrm{SiO}_{2} \\
\mathrm{CaO}-\mathrm{Al}_{2} \mathrm{O}_{3}-\mathrm{SiO}_{2}
\end{array}\right\}+\mathrm{R}_{2} \mathrm{O}+\mathrm{H}_{2} \mathrm{O} \rightarrow \begin{gathered}
\mathrm{R}_{2} \mathrm{O}-\mathrm{Al}_{2} \mathrm{O}_{3}-\mathrm{SiO}_{2}-\mathrm{H}_{2} \mathrm{O} \\
\mathrm{CaO}-\mathrm{R}_{2} \mathrm{O}-\mathrm{Al}_{2} \mathrm{O}_{3}-\mathrm{SiO}_{2}-\mathrm{H}_{2} \mathrm{O}
\end{gathered}
$$

where $\mathrm{R}-\mathrm{Na}, \mathrm{K}, \mathrm{Li}, \mathrm{Rb}, \mathrm{Cs}$.

The idea of using these systems as cementitious materials was based, first of all, on geological data about sodium-potassium-calcium aluminosilicate compounds, which have the higher stability and resistance to atmospheric reagents and are widely present in the Earth's Crust. Second, this idea was based on the results of experimental studies, which proved that alkali hydroxides and salts of alkali metals came into interaction with clay minerals, aluminosilicate glasses and crystalline substances of natural and artificial origin with the formation of waterresistant alkaline and alkaline-alkali earth aluminosilicate hydration products analogous to natural minerals of the zeolite and mica types [6,7].

A classification proposed by Pavel Krivenko in [8] is based on characteristic features of hydration products of the alkali-activated cements, the "edge" variants of which may be represented by the compounds of two types: alkaline aluminosilicate hydrates of the system $\mathrm{R}_{2} \mathrm{O}-\mathrm{Al}_{2} \mathrm{O}_{3}-\mathrm{SiO}_{2}-\mathrm{H}_{2} \mathrm{O}$ and alkali earth silicate hydrates of the system $\mathrm{CaO}-\mathrm{SiO}_{2}-\mathrm{H}_{2} \mathrm{O}$.

A variety of mixed alkaline-alkali earth aluminosilicate hydrates may fall within these "edge" variants. A cement stone hydration product phase composition is determined by constituent raw materials (Table 3 ).

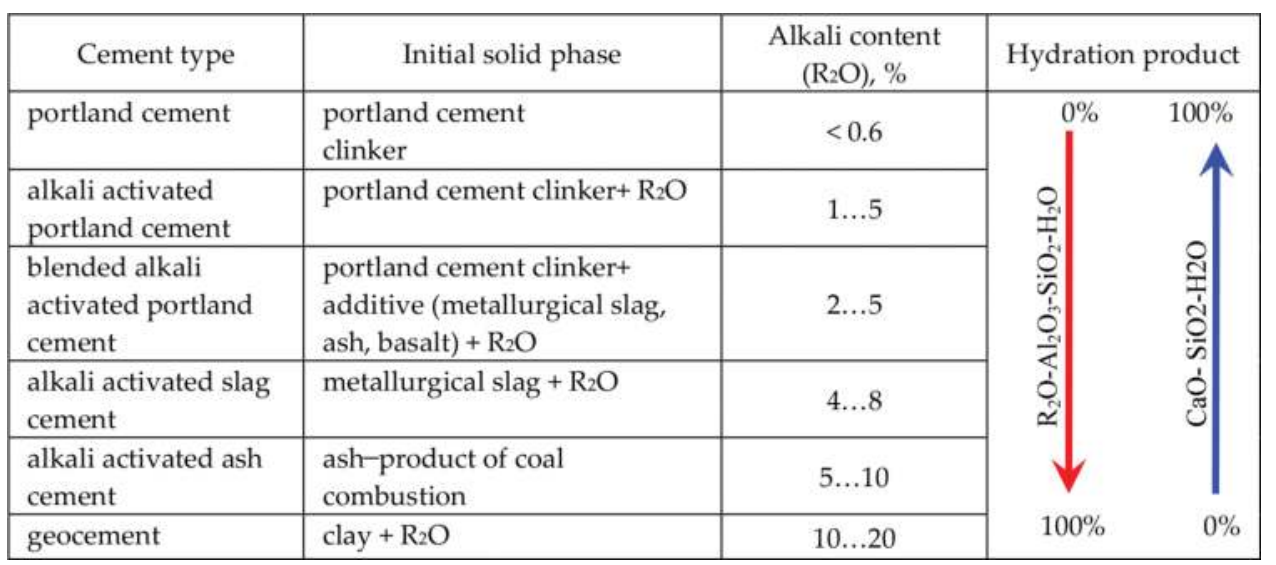

Table 3. Mineralogical composition of cement hydration products vs. type of initial aluminosilicate component.

Strength classes of the alkali-activated cements (compressive strength at age of 28 days) are designated in the national standard of Ukraine DSTU B V.2.7-181:2009 “Cements, alkaline" [9]. High properties of the alkali-activated cement stone are attributed to its structure, which is 
different from that of portland cement, considerably lower solubility of hydration products and absence in them of $\mathrm{Ca}(\mathrm{OH})_{2}$ and calcium sulphoaluminate hydrates $[10,11]$.

\section{Alkali-activated cement concretes}

\subsection{Strength properties}

According to the national standard of Ukraine [12], heavyweight and super heavyweight alkali-activated cement concretes are designated in classes in compressive strength at standard age (28 days).

In compressive strength, the alkali-activated cement concretes are designated, similar to EN-206, as below:

C8/10; C12/15; C16/20; C20/25; C25/30;C30/37; C35/45; C40/50; C45/55; C50/60; C55/67; C60/75; C70/85; C80/95; C90/105; C100/115; C110/125.

In flexural strength, the alkali-activated cement concretes are designated as below:

in axial tension: $\mathrm{C}_{\mathrm{t}} 0.8 ; \mathrm{C}_{\mathrm{t}} 1.2 ; \mathrm{C}_{\mathrm{t}} 1.6 ; \mathrm{C}_{\mathrm{t}} 2.0 ; \mathrm{C}_{\mathrm{t}} 2.4 ; \mathrm{C}_{\mathrm{t}} 2.8 ; \mathrm{C}_{\mathrm{t}} 3.2 ; \mathrm{C}_{\mathrm{t}} 3.6 ; \mathrm{C}_{\mathrm{t}} 4.0$.

in tensile bending strength: $\mathrm{C}_{\mathrm{tB}} 0.8 ; \mathrm{C}_{\mathrm{tB}} 1.2 ; \mathrm{C}_{\mathrm{tB}} 1.6 ; \mathrm{C}_{\mathrm{tB}} 2.0 ; \mathrm{C}_{\mathrm{tB}} 2.4 ; \mathrm{C}_{\mathrm{tB}} 2.8 ; \mathrm{C}_{\mathrm{tB}} 3.2 ; \mathrm{C}_{\mathrm{tB}} 3.6 ; \mathrm{C}_{\mathrm{tB}} 4.0 ; \mathrm{C}_{\mathrm{tB}} 4.4 ;$ $\mathrm{C}_{\mathrm{tB}} 4.8 ; \mathrm{C}_{\mathrm{tB}} 5.2 ; \mathrm{C}_{\mathrm{tB}} 5.6 ; \mathrm{C}_{\mathrm{tB}} 6.0 ; \mathrm{C}_{\mathrm{tB}} 6.4 ; \mathrm{C}_{\mathrm{tB}} 6.8 ; \mathrm{C}_{\mathrm{tB}} 7.2 ; \mathrm{C}_{\mathrm{tB}} 7.6 ; \mathrm{C}_{\mathrm{tB}} 8.0 ; \mathrm{C}_{\mathrm{tB}} 8.4 ; \mathrm{C}_{\mathrm{tB}} 8.8$.

where $C_{t}$ is the characteristic strength in axial tension (MPa) and $C_{t B}$ is the characteristic tensile bending strength $(\mathrm{MPa})$.

As a rule, tensile strength of coarse aggregates in the alkali-activated cement concrete constitutes $10-20 \%$ of compressive strength, depending upon type and density of alkaline activator and alkali-activated cement composition.

Strength of the alkali-activated cement concretes is kept under control, chiefly, by a proper choice of alkaline activator and its content. The greatest effect on strength characteristics is made by soluble sodium silicates. The alkali-activated cement concretes made using sodium silicates have high compressive strength reaching 120-140 MPa. They have close values of compressive strength measured on cubes not depending upon a modulus of basicity and slag content. This is especially clearly expressed in the steam-cured alkali-activated cement concretes. A conclusion was drawn that the lowering of the slag content in the concrete mix from 500 to $300 \mathrm{~kg}$ per $1 \mathrm{~m}^{3}$, the alkaline activator represented by sodium silicates, would affect early strength gain and has no any effect on values of final compressive strength. Strength of the alkali-activated cement concretes made using sodium carbonate as alkaline activator varies between 45 and $80 \mathrm{MPa}$. Type of slag also affects strength gain, and this is especially clearly expressed in the alkali-activated cement concretes that hardened in normal conditions, which continue to attain strength at the later ages. With decrease in blast-furnace slag basicity and slag content, the strength of these concretes will decrease by 10-15 MPa. The highest compressive strength (116-123 MPa) is characteristic of the steam-cured alkali-activated cement concretes made using neutral blast-furnace slags and low-modulus sodium silicates (silicate 
modulus Ms = 1-2). Strength of the steam-cured alkali-activated cement concretes increases with decrease in silicate modulus of sodium silicate and is higher than that of the concretes that hardened for 28 days in normal conditions. The concretes hardening in normal conditions, similar to steam-cured concretes, exhibit the highest compressive strength in case of using neutral slags and low-modulus sodium silicates. The alkali-activated acid slag cement concretes have rather slow early strength gain. However, after two years the strength has increased by 2-2.6 times. High-modulus sodium silicates are not recommended for the alkaliactivated cement concretes in which acid slags are used and for hardening in water. The above combination of cement components can be used under condition that basicity of the binding system will be increased by introduction of high-basic additives [13, 14].

As follows from Ref. [15], not depending upon slag characteristics and nature of alkaline activator, the alkali-activated cement concretes continue to gain strength steadily in normal conditions, in the air and in water even after they have already gained a 28-day strength.

\subsection{Water permeability}

Water permeability is the most widely used key characteristic of permeability of concrete and is expressed as the highest pressure of water at which water still does not penetrate into the test specimen and this characteristic is called a "filtration coefficient". This coefficient is expressed as a quantity of liquid penetrating through a unit of cross section per unit of time at head gradient of 1 .

The alkali-activated cement concretes, to which more strict requirements (low water permeability and high corrosion resistance) are applied, are classified with regard to water permeability as the following: W2; W4; W6; W8; W10; W12; W14; W16; W18; W20; W25; W30 (Wwater permeability, pressure in atm) [12].

Specific features of pore structure of the alkali-activated cement concretes, their high water retaining capacity and lack of segregation in the alkali-activated cement concrete mixtures result in possibility to design concretes with the lower water permeability [16].

Density of the alkali-activated cement concretes increases, and water permeability decreases with time and depends upon chemical-mineralogical composition, slag fineness, and cement content (Tables 4 and 5).

\begin{tabular}{llllll}
\hline Characteristics of water permeability & \multicolumn{6}{l}{ Slag fineness $\left(\mathbf{m}^{2} / \mathbf{k g}\right)$} & $($ measured by Blaine) \\
\cline { 2 - 6 } & $\mathbf{2 3 0}$ & $\mathbf{3 0 0}$ & $\mathbf{4 2 0}$ & $\mathbf{5 1 0}$ & $\mathbf{6 0 0}$ \\
\hline Pressure at which filtration occurs $(\mathrm{MPa})$ & 2.5 & 3.7 & 4.1 & 4.3 & 3.6 \\
Filtration coefficient $\left(\mathrm{K}_{\mathrm{f}} \cdot 10^{-13}\right)(\mathrm{cm} / \mathrm{s})$ & 4.7 & 3.1 & 0.6 & 0.1 & 0.9 \\
\hline
\end{tabular}

Table 4. Water permeability of alkali-activated slag cement stone vs. slag fineness. 


\begin{tabular}{|c|c|c|c|c|c|c|}
\hline \multicolumn{2}{|c|}{$\begin{array}{l}\text { Concrete mix design } \\
(\%)\end{array}$} & \multirow[t]{2}{*}{ w/c } & \multirow[t]{2}{*}{$\begin{array}{l}\text { Water adsorption } \\
(\%)\end{array}$} & \multirow[t]{2}{*}{$\begin{array}{l}\text { Compressive } \\
\text { strength (MPa) }\end{array}$} & \multirow{2}{*}{$\begin{array}{l}\text { Pressure at which } \\
\text { filtration is observed } \\
(\mathrm{MPa})\end{array}$} & \multirow[t]{2}{*}{$\begin{array}{l}\text { Filtration coefficient } \\
(\mathrm{cm} / \mathrm{s})\end{array}$} \\
\hline Slag & Sand & & & & & \\
\hline 15 & 85 & 0.60 & 8.3 & 30.1 & 0.4 & $1.3 \times 10^{-6}$ \\
\hline 20 & 80 & 0.40 & 7.2 & 39.7 & 0.8 & $5.3 \times 10^{-7}$ \\
\hline 25 & 75 & 0.36 & 4.1 & 45.5 & 1.8 & $0.8 \times 10^{-10}$ \\
\hline 30 & 70 & 0.33 & 3.7 & 56.7 & 3.4 & $0.4 \times 10^{-11}$ \\
\hline
\end{tabular}

Table 5. Water permeability of fine aggregate alkali-activated slag cement concretes vs. slag content.

Strength gain and decrease in water permeability of the alkali-activated cement concrete depend upon the cement content: with the cement content reaching $20 \%$, a decrease in water permeability while hardening of the concrete specimens in high humidity conditions has been reported: by 20 times after 1 year and as much as by 200 times after 5 years. The concretes with the cement content between 25 and $40 \%$ at this age were dense enough not to allow water to penetrate into them even at pressures of 4-5 $\mathrm{MPa}$ [15].

Water permeability of the alkali-activated cement concretes decreases in case of using aggregates with properly selected particle size distribution providing minimum void content. So, the lowest value $\left(\mathrm{K}_{\mathrm{f}}=0.9 \times 10^{-12} \mathrm{~cm} / \mathrm{s}\right)$ corresponds to void content of $32.3 \%$. Water permeability of the alkali-activated cement concretes can be improved by addition of clays, which, participating in the structure formation processes, increase density of the concrete. A determining role is played by mineralogical composition of clays. The fine aggregate alkali-activated cement concrete with the highest density was produced using sands containing $10 \%$ of coal and mining wastes. Glauconite clay, in its action on water permeability, is similar to kaolinite clay, and its maximum allowed quantity is $5 \%$. The use of bentonite clay is found to be of no favour due to its coagulation during mixing with alkaline activator solutions.

Filtration coefficient of the alkali-activated cement concretes made using aggregates containing up to $15 \%$ of clay, at the initial test ages, due to its slow interaction with alkaline activators, remained rather high $\left(\mathrm{K}_{\mathrm{f}}=3 \times 10^{-9} \mathrm{~cm} / \mathrm{s}\right)$. However, after 1 year it has decreased by $5-7$ times, after 5 years by 20 times. The decrease in water permeability can be provided by application of special techniques of mixing, in particular, under vibration which was found to decrease filtration coefficient by 25-30 times compared to mixing in traditional mixers.

The most favourable conditions which allow for to reach similar low water permeability, as those of the concretes hardened in normal conditions, are: steam curing in closed moulds at $T=373 \mathrm{~K}$ with a temperature rise for $3-4 \mathrm{~h}$ and isothermal heating for $4 \mathrm{~h}$. The longer isothermal curing has no sense since a density of the concrete does not change.

According to long-term test results, strength, density, and water permeability of the alkaliactivated cement concretes tended to improve with time (Figure 1) not depending upon applied curing conditions, but with the higher rate when the concrete specimens were allowed to cure in water and in high humidity conditions. 


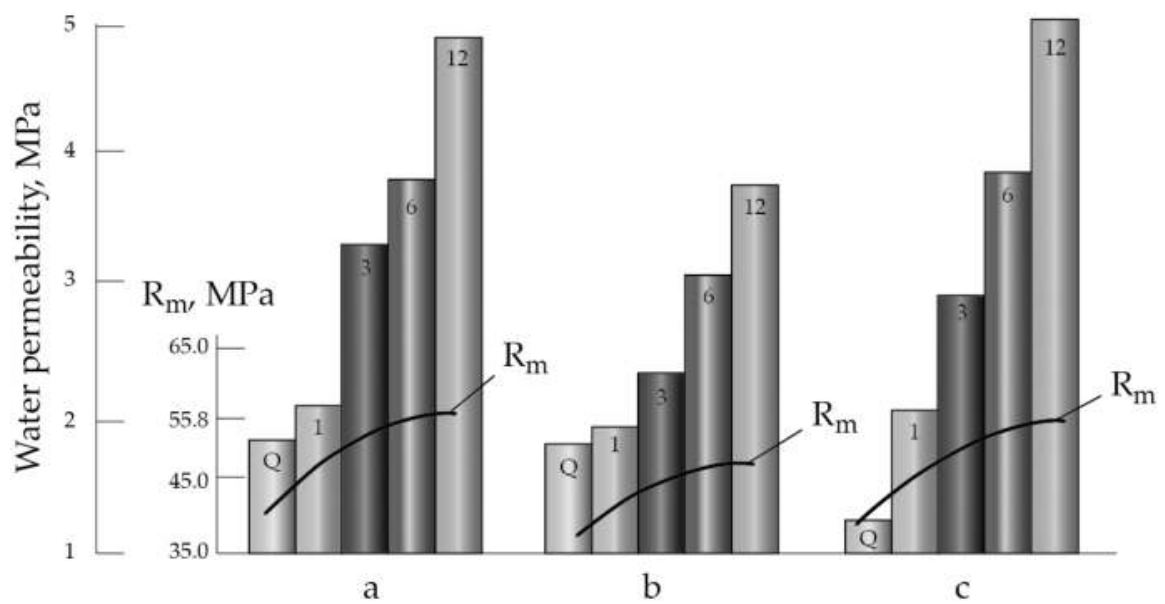

Figure 1. Compressive strength gain $(\mathrm{MPa})$ and water permeability $(\mathrm{MPa})$ of alkali-activated cement concretes vs. cure conditions: $\mathbf{a}$-high humidity; $\mathbf{b}-$ dry; $\mathbf{c}-$ in water and cure regimes: $\mathrm{Q}-$ after steam curing; $1,3,6,12-$ at age of 1,3 , 6 , and 12 months, respectively.

Due to specific features of a capillary pore structure, water permeability of the alkali-activated cement concretes remained almost unchanged and still rather low after attacks of cyclic unfavourable conditions: heating-cooling, wetting-drying, freezing-thawing (Table 6). Water permeability as a function of concrete structure is the most important physical characteristic defining degree of deterioration under exposure of various aggressive environments, since corrosion processes start at the interfacial surface of external environment and concrete and proceed inward the concrete-reaching pores and capillaries.

Water permeability of the alkali-activated cement concrete can be improved by optimization of its composition with application of conventional techniques.

\begin{tabular}{|c|c|c|c|c|c|c|c|c|c|}
\hline \multirow[t]{4}{*}{ Composition no } & \multirow{2}{*}{\multicolumn{3}{|c|}{$\begin{array}{l}\text { Heating-cooling } \\
\text { Cycles }\end{array}$}} & \multicolumn{3}{|c|}{ Wetting-drying } & \multicolumn{3}{|c|}{ Freezing-thawing } \\
\hline & & & & & & & & & \\
\hline & 50 & 100 & 200 & 50 & 100 & 200 & 50 & 100 & 200 \\
\hline & \multicolumn{9}{|c|}{ Permeability expressed as pressure (MPa) } \\
\hline 1 & 1 & 8 & 7 & 13 & 15 & 14 & 15 & 17 & 16 \\
\hline 2 & 5 & 5 & 4 & 9 & 10 & 11 & 11 & 12 & 13 \\
\hline
\end{tabular}

Notes

1. Concrete mix design (composition no. 1 ), $1 \mathrm{~m}^{3}$ : ground granulated blast-furnace slag $-500 \mathrm{~kg}$, ultrafine (desert) sand $-300 \mathrm{~kg}$, coarse aggregate $(5 / 20)-1175 \mathrm{~kg}$, and sodium metasilicate (density $\left.=1220 \mathrm{~kg} / \mathrm{m}^{3}\right)-200 \mathrm{l}$.

2. Concrete mix design (composition no. 2), $1 \mathrm{~m}^{3}$ : portland cement $-500 \mathrm{~kg}$, river sand $-300 \mathrm{~kg}$, coarse aggregate (5/20) $-1175 \mathrm{~kg}$, and water -2001 .

Table 6. Changes in water penetration of alkali-activated slag cement concrete after cyclic exposures. 


\subsection{Corrosion resistance in mineral environments}

Durability of the alkali-activated cement concrete in mineral salt solutions is affected by ion composition, concentration and exposure conditions and is predetermined by specific features of micro- and macrostructure affected by slag composition, type and quantity of alkaline activator, as well as by cure conditions. The alkali-activated cement concretes exhibit high resistance in solutions of magnesium chlorides and nitrates considerably exceeding those of sulphate-resisting portland cements [17].

Resistance of the alkali-activated cement concretes in sulphate solutions is determined by cations of sulphate salts as well as by alkali-activated cement composition. In sodium sulphate solutions, the alkali-activated cement concretes, not depending upon alkali-activated cement composition, are not subjected to deterioration. This is attributed to lack of conditions for the formation of insoluble corrosion products.

Sulphates of polyvalent metals (magnesium, manganese, aluminium, nickel, copper, zinc, etc.), as well as those of ammonia that form insoluble (silicate hydrates, hydroxides) or volatile (ammonia) compounds, are more aggressive environments. These compounds react actively with the alkali-activated cement stone solid phase with the formation of gypsum dehydrate. A degree of aggressiveness of these sulphate compounds is determined by properties of cations, permeability of corrosion products and $\mathrm{pH}$-values of the formed hydroxides.

Depending upon properties of cation, resistance of the alkali-activated slag cements in sulphate solutions decreases in the following sequence: $\mathrm{Na}^{+}>\mathrm{Zn}^{2+}>\mathrm{Cu}^{2+}>\mathrm{Ni}^{2+}>\mathrm{Al}^{3+}>\mathrm{NH}_{4}^{+}>\mathrm{Mg}^{2+}>$ $\mathrm{Mn}^{2+}[18]$.

\begin{tabular}{|c|c|c|c|c|c|c|c|c|c|}
\hline \multicolumn{2}{|c|}{ Nos Alkaline activator } & \multicolumn{8}{|c|}{ Coefficient of corrosion resistance after immersion, duration in months } \\
\hline & & \multicolumn{4}{|c|}{$3 \%$ concentration } & \multicolumn{4}{|c|}{$6 \%$ concentration } \\
\hline & & 1 & 3 & 6 & 12 & 1 & 3 & 6 & 12 \\
\hline 1 & Sodium hydroxide & 1.02 & 1.00 & 0.63 & 0 & 1.15 & - & - & - \\
\hline 2 & Sodium carbonate & 1.10 & 0.74 & 0.65 & 0 & 1.18 & 0.42 & 0.29 & 0 \\
\hline 3 & Sodium metasilicate & 1.01 & 1.04 & 1.24 & 0 & 1.49 & 0.43 & 0.27 & 0 \\
\hline 4 & Sodium disilicate & 1.37 & 1.28 & 3.60 & 1.35 & 1.51 & 1.40 & 2.87 & 1.07 \\
\hline 5 & Sodium silicate $(\mathrm{Ms}=3.0)$ & 2.97 & 4.49 & 9.90 & 3.09 & 3.62 & 9.05 & 13.96 & 2.50 \\
\hline
\end{tabular}

Table 7. Corrosion resistance of alkali-activated slag cement concretes made with various alkaline activators in $\mathrm{MgSO}_{4}$ solutions.

Corrosion of the alkali-activated cement stone in $\mathrm{MgSO}_{4}$-solutions takes place similar to corrosion of portland cement stone: occurrence of cracks, mainly perpendicular to a longitudinal axis of a specimen, curvature of the specimen, increase in linear dimensions and volume, deterioration. 
At equal densities of alkaline activators, the corrosion resistance of the alkali-activated cements in $\mathrm{MgSO}_{4}$ solutions tends to improve depending upon a type of alkaline activator in the following sequence: $\mathrm{NaOH}<\mathrm{Na}_{2} \mathrm{CO}_{3} \approx \mathrm{Na}_{2} \mathrm{SiO}_{3}<\mathrm{Na}_{2} \mathrm{Si}_{2} \mathrm{O}_{5}<\mathrm{Na}_{2} \mathrm{O} \cdot 2.65 \mathrm{SiO}_{2}$ (Table 7).

An alkaline activator solution content to slag content ratio affects corrosion resistance in $\mathrm{MgSO}_{4}$ solutions. The higher is this ratio, the lower is the corrosion resistance due to the higher porosity and higher is the permeability of the resulted stone.

Heat-treated alkali-activated cement concretes made with sodium silicate (Ms $=1-3)$ have the lower resistance compared to that of similar concretes that hardened in normal conditions. The use in this case of non-silicate compounds of alkali metals has positive effect on corrosion resistance of the alkali-activated cements in $\mathrm{MgSO}_{4}$ solutions.

In general, the comparative test results of the alkali-activated, portland and sulphate-resisting portland cements showed that in the conditions of full immersion, the alkali-activated cement concretes had higher resistance in the solutions of sodium sulphates $\left(\mathrm{K}_{\mathrm{r} 24} \geq 1\right)$, magnesium chloride, and nitrate and had similar corrosion resistance in marine environment to that of sulphate-resisting cement $\left(\mathrm{K}_{\mathrm{r} 24} \geq 0.55\right.$. Whear: $\mathrm{K}_{\mathrm{r}}$-ratio of strength of a specimen exposed to aggressive environment to that of a specimen stored in water; ${ }_{24}-$ a number of months).

Analysis of specific deterioration of the alkali-activated cement stone and known types of corrosion suggested that alkali-activated cement hydration products were represented by four groups of substances varying in resistance in aggressive environments:

- the most easily dissolved - "free" (unbound) alkaline activator;

- less dissoluble compared to alkalis, but relatively easily dissoluble substances of the sodium silicate or calcium-sodium silicates types that are present in a gel-like state;

- relatively resistant to dissolution calcium silicate hydrates and calcite;

- the most poorly dissoluble crystalline calcium silicate hydrates and sodium aluminosilicate hydrates.

Prevalence of one of these or those groups in the cement hydration products determines variations in corrosion resistance.

\subsection{Corrosion resistance in organic environments}

Corrosion resistance of the alkali-activated slag cement concretes in organic environments is dependent upon an alkali-activated cement composition, character of pore structure of the resulted concrete as well as reactivity of aggressive environments.

Corrosion resistance expressed by $\mathrm{K}_{\mathrm{r}}$ was measured on the specimens made from alkaliactivated and portland cement concretes 24 months after immersion in hydrocarbon media (kerosene, diesel, mineral oil, petroleum) and water as reference medium $\left(\mathrm{K}_{\mathrm{r} 24}\right)$ (Table 8). A conclusion was drawn that corrosion resistance of the alkali-activated cement concretes was higher than that of portland cement concretes. This is explained by formation of the concrete 
structure with the lower capillary porosity and continuation of hydration processes in the alkali-activated cement in organic environments [19].

\begin{tabular}{|c|c|c|c|c|}
\hline \multicolumn{3}{|l|}{ Aggressive environment } & \multicolumn{2}{|c|}{$\begin{array}{l}\text { Variations of } \mathrm{Kr}_{24} \text { after storage in the conditions of full } \\
\text { immersion of concrete specimens made from }\end{array}$} \\
\hline Name & $\mathrm{pH}$ & $\begin{array}{l}\text { Acidity measured } \\
\text { by titration } \\
(\mathrm{mol} / \mathrm{l})\end{array}$ & Alkali-activated cement & Portland cement \\
\hline Gasoline & - & 0.0005 & $0.98 \ldots 0.99$ & $0.98 \ldots 0.99$ \\
\hline Benzene (benzole) & - & 0.0007 & $0.96 \ldots 1.00$ & $0.70 \ldots 0.90$ \\
\hline Kerosene & - & 0.0008 & $0.92 \ldots 0.99$ & $0.60 \ldots 0.78$ \\
\hline Mineral oil & - & 0.0011 & $0.64 \ldots 0.96$ & $0.50 \ldots 0.70$ \\
\hline Diesel & - & 0.0009 & $0.72 \ldots 0.94$ & $0.50 \ldots 0.67$ \\
\hline Sulphur-bearing crude & - & 0.0013 & $0.5 \ldots 0.97$ & $0.56 \ldots 0.40$ \\
\hline Animal fat & - & 0.0500 & $0.56 \ldots 0.97$ & Destroyed \\
\hline $\begin{array}{l}\text { Solution of sugar } 30 \% \\
\text { concentration }\end{array}$ & - & 0.0100 & $0.68 \ldots 1.18$ & $0.30 \ldots 0.64$ \\
\hline $\begin{array}{l}\text { Pickle (saline) solution of } \\
\text { meat processing factory }\end{array}$ & - & - & $0.68 \ldots 1.18$ & $0.30 \ldots 0.64$ \\
\hline $\begin{array}{l}\text { Acetic acid of } 10 \% \\
\text { concentration }\end{array}$ & 2.80 & - & $0.25 \ldots 0.45$ & $0.15 \ldots 0.24$ \\
\hline $\begin{array}{l}\text { Milk acid of } 10 \% \\
\text { concentration }\end{array}$ & 3.45 & - & $0.3 \ldots 0.79$ & $0.20 \ldots 0.35$ \\
\hline
\end{tabular}

Table 8. Resistance of fine aggregate alkali-activated cement and portland cement concretes in various organic environments after 24 months.

Depending upon the alkaline activator used, resistance of the alkali-activated cement concretes in aggressive petroleum environments increases in the following sequence: $\mathrm{NaOH}>$ sodaalkali melt (by-product of chemical industry) $>\mathrm{Na}_{2} \mathrm{CO}_{3}>\mathrm{Na}_{2} \mathrm{SiO}_{3}>\mathrm{Na}_{2} \mathrm{O}_{2} \mathrm{SiO}_{2}$.

High-molecular organic environments are less aggressive for the alkali-activated cement concretes. After 24 months of storage of the specimens in pickle (saline) solution, animal fat and $30 \%$ concentration solution of sugar, the resistance was more than by three times higher compared to that of portland cement concrete.

Resistance of the alkali-activated cement concrete in low-molecular compounds (glycerine, acetic and milk acids) is comparable to that of portland cement concrete and somewhat exceeds it. This may be attributed to the lower solubility of hydration products of the alkali-activated cements and lack of $\mathrm{Ca}(\mathrm{OH})_{2}$, high-basic calcium silicate and aluminate hydrates in the hydration products. 
Thus, on the contrary to conventional cements, the alkali-activated cements exhibit the higher physico-mechanical properties such as strength, water permeability, corrosion resistance. The alkali-activated cements possess a complex of the above properties and can be classified as cements with polyfunctional properties.

\subsection{Biodegradability and bio-fouling}

Capability with regard to biodegradability and bio-fouling was tested according to the following: the specimens were stored in solution of sulphuric acid $(\mathrm{pH}=3-4)$ [20].

After exposure to aggressive environment, the concrete specimens were tested to determine compressive and flexural strength characteristics.

When a ratio of strength after testing to that before testing is higher than 0.8 , the cements are classified as corrosive resistant cements. Test results are given in Table 9.

\begin{tabular}{|c|c|c|c|c|c|c|}
\hline \multirow[t]{3}{*}{ Concrete class } & \multicolumn{6}{|c|}{ Compressive/flexural strength (MPa) after } \\
\hline & 3 months & & 6 months & & 9 months & \\
\hline & Normal curing & In sulphuric acid & Normal curing & In acid solution & Normal curing & In sulphuric acid \\
\hline $\mathrm{C} 45 / 50$ & $53.4 / 11.4$ & $50.5 / 10.7$ & $54.7 / 9.6$ & $60.6 / 11.1$ & $60.7 / 10.6$ & $55.6 / 10.5$ \\
\hline C100/115 & $122.6 / 12.1$ & $105.4 / 11.0$ & $113.1 / 10.3$ & $93.2 / 12.1$ & $115.8 / 12.0$ & $105.8 / 12.0$ \\
\hline
\end{tabular}

Table 9. Strength variations after exposure of aggressive environment.

From given results, both concretes under study showed stability of strength properties even after storage in aggressive environment for 9 months. So, it is clear that the alkali-activated slag concretes are resistant to biodegradability and bio-fouling.

\subsection{Chloride diffusion}

Replacement of portland cement with blast-furnace slag suppresses chloride diffusion in the hardened cement pastes, mortars and concretes [20]. Other study [5] has indicated that the addition of alkalis to blended portland slag cement not only increased cement strength but also decreased chloride diffusion in the cement paste significantly (Figure 2). The other clear trend is that diffusion rate of chloride decreases with increase in slag substitution.

The developed diffusion cell test is often used to measure the apparent diffusivity of $\mathrm{Cl}^{-}$ through hardened cement pastes and concrete. Chloride diffusion test on both the F-cement (a variety of alkali-activated cement) and portland cement pastes indicated that the diffusion rate of $\mathrm{Cl}^{-}$through F-cement pastes is about 30-40 times slower than that through portland cement pastes for a given water-to-cement or water-to-slag ratio (Table 10). It was also noticed that cracks of $10-50$ microns wide, induced by drying below $50 \%$ relative humidity, did not show any influence on the $\mathrm{Cl}^{-}$diffusion rate of the specimens. However, the specimens with cracks wider than 50 microns running through the specimens had much higher $\mathrm{Cl}^{-}$diffusion rate [20]. 


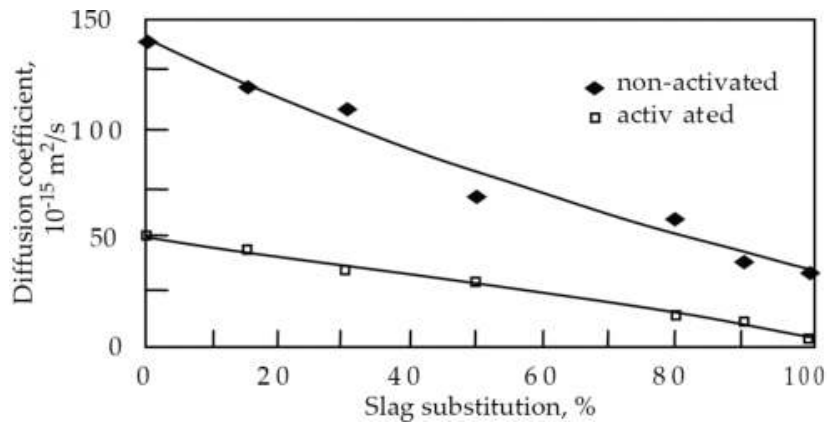

Figure 2. Effect of alkaline activation on chloride diffusion in portland slag cement.

\begin{tabular}{llll}
\hline Nos & Cement paste & Water to cement (slag) ratio & Diffusion coefficient $\left(\mathrm{cm}^{2} / \mathbf{s}\right)$ \\
\hline 1 & Portland cement & 0.23 & $321 \times 10^{-12}$ \\
2 & Alkali-activated slag cement & 0.23 & $75 \times 10^{-12}$ \\
3 & Portland cement & 0.35 & $6390 \times 10^{-12}$ \\
4 & Alkali-activated slag cement & 0.35 & $240 \times 10^{-12}$ \\
\hline
\end{tabular}

Table 10. Chloride permeability test results of various cements [20].

\begin{tabular}{|c|c|c|c|c|c|c|c|}
\hline \multirow[t]{2}{*}{ Age } & \multicolumn{7}{|c|}{ Voltage $-30 \mathrm{~V}$; time $-24 \mathrm{~h}$} \\
\hline & No & $\mathrm{I} 0 / \mathrm{mA}$ & T0/ & If $/ \mathrm{mA}$ & $\mathrm{Tf} /$ & $\mathrm{L} / \mathrm{cm}$ & Dfucc $/ \times 10^{-12}$ \\
\hline \multirow[t]{4}{*}{3 days } & $\mathrm{CH} 1$ & 21.9 & 23.8 & 17.8 & 22.5 & 1.33 & 2.91 \\
\hline & $\mathrm{CH} 2$ & 29.1 & 23.7 & 28.0 & 21.4 & 1.53 & 3.37 \\
\hline & $\mathrm{CH} 3$ & 29.5 & 23.5 & 19.2 & 22.2 & 1.55 & 3.42 \\
\hline & Mean & & & & & & 3.23 \\
\hline \multirow[t]{4}{*}{7 days } & $\mathrm{CH} 1$ & 22.8 & 25.9 & 16.4 & 23.7 & 1.27 & 2.78 \\
\hline & $\mathrm{CH} 2$ & 18.6 & 25.8 & 15.8 & 23.6 & 1.22 & 2.67 \\
\hline & $\mathrm{CH} 3$ & 23.6 & 25.5 & 21.7 & 23.8 & 1.37 & 3.01 \\
\hline & Mean & & & & & & 2.82 \\
\hline \multirow[t]{4}{*}{28 days } & $\mathrm{CH} 1$ & 16.8 & 24.2 & 20.3 & 22.8 & 0.81 & 1.71 \\
\hline & $\mathrm{CH} 2$ & 19.4 & 24.1 & 16.4 & 22.8 & 0.79 & 1.66 \\
\hline & $\mathrm{CH} 3$ & 21.7 & 23.9 & 20.8 & 22.7 & 1.04 & 2.53 \\
\hline & Mean & & & & & & 1.71 \\
\hline
\end{tabular}

Notes: I0, T0, initial current (T); If, Tf-final current (T); L-diffuse depth; Dfucc-diffusion coefficient.

Table 11. Chlorine ions diffusion parameters [20]. 
Analysis of the obtained results showed that all concretes had good resistance to chloride ions penetration. According to ASTM standard, such properties are characteristic of exclusively for polymer concretes. Thus, it is possible to predict high durability of all tested concretes.

Dependences between chloride diffusion and age of concrete are shown in Table 11.

\subsection{Freeze-thaw resistance}

A key factor affecting durability of a cement stone is its pore structure which determines, in particular, its freeze-thaw resistance. For example, frost destruction of water-saturated portland cement stone takes place, chiefly, during spasmodic freezing of microcapillary water during a period starting from ice formation and until $\mathrm{T}=253 \mathrm{~K}$.

Frost destruction of the water-saturated alkali-activated cement stone occurs when the remaining portions of microcapillary moisture get frozen at temperatures below $\mathrm{T}=223 \mathrm{~K}$.

At temperatures of $243 \mathrm{~K}$, the alkali-activated cement stone is subjected to residual deformations; after cooling to $\mathrm{T}=233 \mathrm{~K}$, the residual deformations were $0.01 \mathrm{~mm} / \mathrm{m}$, after cooling to $\mathrm{T}=213 \mathrm{~K}-0.15 \mathrm{~mm} / \mathrm{m}$ (Figure 3 ) or of about $10 \%$ of residual deformations after freezing to $173 \mathrm{~K}$ and thawing [21].

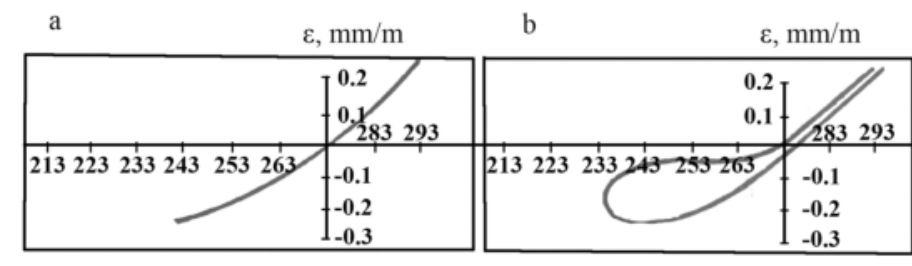

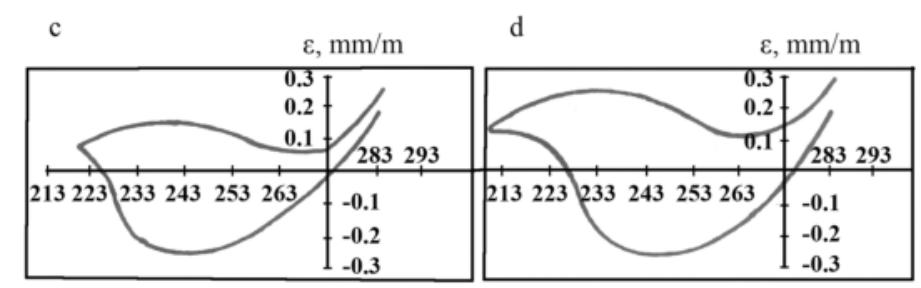

Figure 3. Deformations of alkali-activated slag cement concrete (water-to-slag ratio $=0.3$ ) under attacks of freezingthawing: $\mathbf{a}-\mathrm{T}=243 \mathrm{~K} ; \mathbf{b}-\mathrm{T}=234 \mathrm{~K} ; \mathbf{c}-\mathrm{T}=219 \mathrm{~K} ; \mathbf{d}-\mathrm{T}=212 \mathrm{~K}$.

Differences in mechanism of temperature-induced deformations of the water-saturated portland cement and alkali-activated cement stones are attributed to the presence in the capillaries of the latter of true solutions of strong electrolytes, the lowering of the freezing temperature and promoting step-by-step removal of water due to freezing. Mechanism of water removal from a pore space of the alkali-activated cement stone is different from that in portland cement stone, thus determining a difference in the rate of their deformations in the 
process of cooling and heating. Pore liquid in portland cement stone capillaries gets frozen spasmodically with elimination of meniscus and in the capillaries of the alkali-activated cement stone step-by-step, with maintaining the meniscus in a frozen state, resulted in the lowering of temperature of precipitation (settling-out) of eutectic mixtures.

A freezing temperature of pore liquid is largely determined by a type of alkaline activator. For example, in case of potash a freezing temperature of the eutectic mixture is $237 \mathrm{~K}$, in case of soda only $270.9 \mathrm{~K}$. The other reason causing different behaviour of the frozen water-saturated specimens from portland cement and alkali-activated slag cement concretes is attributed to specific features of their pore structure; in particular, the alkali-activated cement stone is characteristic of the increased microcapillary porosity.

A temperature of ice formation in the alkali-activated cement concretes is shifted to the region of the lower temperatures, since contents of fine pores $(3-8 \mathrm{~nm})$ in the alkali-activated cement stone are somewhat higher than those in portland cement concrete.

The alkali-activated cement concretes made with soluble sodium silicates have the highest freeze-thaw resistance, high density and strength. Their freeze-thaw resistance, depending upon production technology and other factors affecting strength characteristics, is $300-1300$ cycles [22].

\subsection{Weather resistance}

Alternate (cyclic) wetting-drying, carbon dioxide and temperature variations are among factors associated with weather exposure.

Long-term cyclic wetting-drying will increase irreversible shrinkage deformations and deterioration of the concrete structure and may cause in the future loss of its load carrying ability.

Alternate wetting-drying of the alkali-activated cement concretes has no effect on its compressive strength: after 50 cycles of wetting-drying, a compressive strength of the alkaliactivated cement concrete made with sodium carbonate of technical grade (commercial product) in solution has lowered by $4 \%$, with sodium metasilicate-by $1.5 \%$ [13].

Strength properties of the alkali-activated cement concrete exposed to alternating atmospheric conditions can be improved through regulation of rate of crystallization of a gel phase, adjustment of the hydration product phase composition and directed synthesis of the materials with a required pore structure The influence of these factors on durability of the artificial stone is evident and may be taken in account in choosing the appropriate process parameters for manufacture of the alkali-activated cement concrete with desired physico-mechanical characteristics.

Weather resistance was tested according to the prescribed testing procedure [23]. The specimens were immersed in water for $4 \mathrm{~h}$ and then dried at temperatures of $378-383 \mathrm{~K}$ for $15 \mathrm{~h}$.

Three characteristics were studied: compressive and flexural strength and mass changes after testing. Test results are given in Tables 12 and 13. 


\begin{tabular}{|c|c|c|c|c|c|c|c|c|}
\hline \multirow[t]{3}{*}{ Sample No } & \multicolumn{4}{|c|}{ Drying-wetting } & \multicolumn{4}{|c|}{ Normal curing } \\
\hline & \multicolumn{2}{|c|}{ C70/85 } & \multicolumn{2}{|c|}{ C100/115 } & \multicolumn{2}{|c|}{ C70/85 } & \multicolumn{2}{|c|}{ C100/115 } \\
\hline & Flex. & Comp. & Flex. & Comp. & Flex. & Comp. & Flex. & Comp. \\
\hline \multicolumn{9}{|c|}{ After 75 cycles (MPa) } \\
\hline Sample no 1 & 8.2 & 76.9 & 11.0 & 116.3 & 9.9 & 50.9 & 10.8 & 103.0 \\
\hline Sample no 2 & 7.1 & 75.6 & 9.9 & 113.8 & 9.8 & 46.4 & 11.7 & 110.1 \\
\hline Sample no 3 & 6.4 & 74.5 & 10.0 & 116.3 & 9.0 & 48.1 & 11.2 & 105.3 \\
\hline Mean strength & 7.2 & 75.7 & 10.3 & 115.5 & 9.6 & 48.5 & 11.2 & 106.1 \\
\hline \multicolumn{9}{|c|}{ After 100 cycles (MPa) } \\
\hline Sample no 1 & 8.7 & 88.1 & 11.4 & 115.1 & 9.5 & 51.3 & 11.6 & 113.1 \\
\hline Sample no 2 & 8.5 & 87.1 & 12.1 & 117.8 & 9.1 & 52.3 & 11.8 & 108.5 \\
\hline Sample no 3 & 7.6 & 88.2 & 12.1 & 115.6 & 9.7 & 58.0 & 11.8 & 110.2 \\
\hline Mean strength & 8.3 & 87.8 & 11.9 & 116.1 & 9.4 & 53.9 & 11.7 & 110.6 \\
\hline \multicolumn{9}{|c|}{ After 150 cycles (MPa) } \\
\hline Sample no 1 & 7.4 & 83.3 & 11.1 & 119.1 & 8.2 & 48.9 & 11.9 & 112.9 \\
\hline Sample no 2 & 7.8 & 79.3 & 10.4 & 120.9 & 10.1 & 44.2 & 11.9 & 113.6 \\
\hline Sample no 3 & 8.5 & 83.3 & 11.5 & 117.3 & 8.5 & 46.7 & 11.6 & 110.7 \\
\hline Mean strength & 7.9 & 82.0 & 11.0 & 119.1 & 8.9 & 46.6 & 11.8 & 112.4 \\
\hline \multicolumn{9}{|c|}{ After 200 cycles (MPa) } \\
\hline Sample no 1 & 9.2 & 86.7 & 11.0 & 110.1 & & & & \\
\hline Sample no 2 & 8.2 & 92.2 & 11.5 & 125.1 & & & & \\
\hline Sample no 3 & 8.1 & 85.1 & 9.0 & 112.4 & & & & \\
\hline Mean strength & 8.5 & 88.0 & 11.3 & 113.9 & & & & \\
\hline
\end{tabular}

Table 12. Residual strength characteristics of alkali-activated slag cements concretes vs. curing conditions.

Test results showed that both concretes passed 200 cycles without any sign of deterioration.

\subsection{Wear resistance}

Wearing can be classified into three categories: abrasion, erosion and cavitation [20].

Specific features of wear in abrasion of the alkali-activated cement stone are attributed to its mineralogical and phase compositions, size of crystals and specific surface of a solid phase. Due to intensive processes of structure formation, a time-based approach to assessment of this characteristic was applied.

Tests were carried out according to a standard procedure on cube specimens $(70 \times 70 \times 70 \mathrm{~mm})$. A standard river sand was used as an abrasive material. Wear in abrasion was expressed as changes of mass and linear dimensions of the specimens subjected to wear. The results of wear in abrasion of the alkali-activated slag cement concrete are reported in (Table 14) [24]. 


\begin{tabular}{|c|c|c|c|c|}
\hline & \multicolumn{2}{|l|}{ C70/85 } & \multicolumn{2}{|c|}{ C100/115 } \\
\hline & Before & After & Before & After \\
\hline \multicolumn{5}{|l|}{ After 75 cycles (g) } \\
\hline Sample no 1 & 559.0 & 558.0 & 562.0 & 560.0 \\
\hline Sample no 2 & 561.0 & 560.0 & 562.0 & 556.0 \\
\hline Sample no 3 & 563.0 & 563.0 & 570.0 & 564.0 \\
\hline Mean mass & 561.0 & 560.3 & 564.7 & 560.0 \\
\hline Mass change (\%) & 0.125 & & 0.832 & \\
\hline \multicolumn{5}{|l|}{ After 100 cycles (g) } \\
\hline Sample no 1 & 553.0 & 555.0 & 562.0 & 559.0 \\
\hline Sample no 2 & 564.0 & 567.0 & 578.0 & 571.0 \\
\hline Sample no 3 & 558.0 & 561.0 & 573.0 & 573.0 \\
\hline Mean mass & 558.3 & 561.0 & 571.0 & 567.7 \\
\hline Mass change (\%) & -0.484 & & 0.578 & \\
\hline \multicolumn{5}{|l|}{ After 150 cycles (g) } \\
\hline Sample no 1 & 554.0 & 555.0 & 578.0 & 572.0 \\
\hline Sample no 2 & 553.0 & 554.0 & 563.0 & 555.0 \\
\hline Sample no 3 & 555.0 & 558.0 & 571.0 & 561.0 \\
\hline Mean mass & 554.0 & 555.7 & 570.7 & 562.7 \\
\hline Mass change (\%) & -0.307 & & 1.402 & \\
\hline \multicolumn{5}{|l|}{ After 200 cycles (g) } \\
\hline Sample no 1 & 567.0 & 562.0 & 573.0 & 568.0 \\
\hline Sample no 2 & 564.0 & 559.0 & 566.0 & 561.0 \\
\hline Sample no 3 & 562.0 & 556.0 & 562.0 & 560.0 \\
\hline Mean mass & 564.3 & 559.0 & 567.0 & 563.0 \\
\hline Mass change (\%) & 0.939 & & 0.705 & \\
\hline
\end{tabular}

Table 13. Mass changes of alkali-activated slag cement concretes.

Wear resistance of the alkali-activated slag cement concrete decreases with its compressive strength increase. This dependence can be approximated to a linear one and described by the following expression [25]:

$$
\mathrm{W}=\mathrm{C}-\mathrm{K} \cdot \mathrm{R}_{\mathrm{m}}
$$

where $W$ is the wear of concrete in abrasion, $\mathrm{g} / \mathrm{cm}^{2} ; C, K$ is the dimensionless coefficients; $R_{m}$ is the compressive strength of concrete measured on cubes (MPa). 


\begin{tabular}{|c|c|c|c|c|c|c|c|}
\hline \multicolumn{4}{|c|}{ Sodium carbonate } & \multicolumn{4}{|l|}{ Sodium silicate } \\
\hline \multicolumn{2}{|c|}{ Normal conditions } & \multicolumn{2}{|l|}{ Steam curing } & \multicolumn{2}{|c|}{ Normal conditions } & \multicolumn{2}{|l|}{ Steam curing } \\
\hline $\begin{array}{l}\text { Compressive } \\
\text { strength (MPa) }\end{array}$ & $\begin{array}{l}\text { Wear in } \\
\text { abrasion } \\
\left(\mathrm{g} / \mathrm{cm}^{2}\right)\end{array}$ & $\begin{array}{l}\text { Compressive } \\
\text { strength (MPa) }\end{array}$ & $\begin{array}{l}\text { Wear in } \\
\text { abrasion } \\
\left(\mathrm{g} / \mathrm{cm}^{2}\right)\end{array}$ & $\begin{array}{l}\text { Compressive } \\
\text { strength (MPa) }\end{array}$ & $\begin{array}{l}\text { Wear in } \\
\text { abrasion } \\
\left(\mathrm{g} / \mathrm{cm}^{2}\right)\end{array}$ & $\begin{array}{l}\text { Compressive } \\
\text { strength (MPa) }\end{array}$ & $\begin{array}{l}\text { Wear in } \\
\text { abrasion } \\
\left(\mathrm{g} / \mathrm{cm}^{2}\right)\end{array}$ \\
\hline 35.0 & 0.470 & 33.0 & 0.550 & 37.5 & 0.462 & 40.0 & 0.497 \\
\hline 37.0 & 0.437 & 34.0 & 0.547 & 44.5 & 0.441 & 42.0 & 0.484 \\
\hline 47.5 & 0.450 & 41.0 & 0.540 & 59.5 & 0.465 & 61.5 & 0.455 \\
\hline 52.5 & 0.394 & 48.5 & 0.490 & 65.0 & 0.420 & 64.0 & 0.418 \\
\hline 54.5 & 0.420 & 51.0 & 0.470 & 66.5 & 0.377 & 67.5 & 0.423 \\
\hline 62.0 & 0.358 & 59.0 & 0.453 & 80.0 & 0.379 & 83.5 & 0.362 \\
\hline 67.5 & 0.330 & 60.5 & 0.430 & 88.5 & 0.368 & 89.5 & 0.375 \\
\hline
\end{tabular}

Table 14. Wear in abrasion of alkali-activated slag cement concretes vs. compressive and curing conditions.

Wear in abrasion of the alkali-activated cement concrete tends to reduce with time, especially until the age of 180 days, that is, during a period of intensive structure formation. Analyzing the results of measurements of wear of the alkali-activated cement concrete specimens for a period of 24 months suggested to reveal a correlation between age of the alkali-activated cement concrete and express it mathematically [24]:

$$
W=\frac{W^{28}}{0.6 \lg T}
$$

where $W$ is the wear of concrete in abrasion, $\mathrm{g} / \mathrm{cm}^{2} ; W^{28}$ is the same, at age of 28 days; and $T$ is the age of concrete, days.
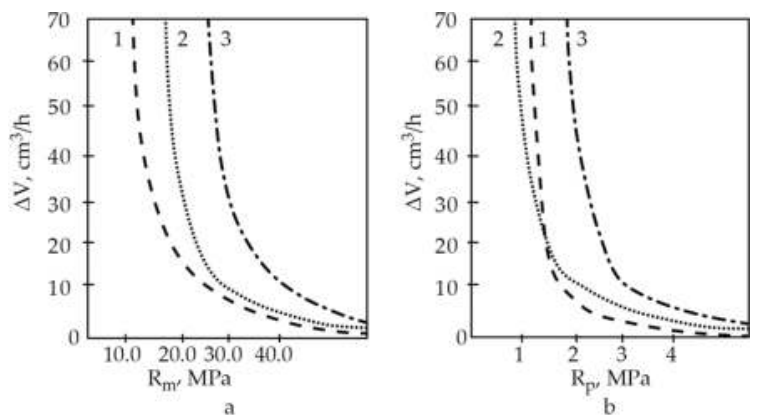

Figure 4. Correlation between the rate of cavitation-induced degradation of various concretes vs. compressive (a) and tensile strength (b): 1-fine aggregate alkali-activated cement concrete; 2 -fine aggregate portland cement concrete; 3 -coarse aggregate portland cement concrete. 
The alkali-activated cement concretes exhibit not only high wear resistance in normal service conditions, but are resistant to cavitation damage (Figure 4). Cavitation resistance of the alkaliactivated cement concrete, expressed as specific mass change of the concrete per unit of time (measured rate of deterioration, $\mathrm{cm}^{3} / \mathrm{h}$ ), correlates well with strength characteristics and is described by a hyperbolic-type equation.

Cavitation-induced wear (cavitation damage) on concrete surface is most common in case of spillway in dams. This leads to cracks on the concrete surface which further increases the risk of damage to concrete due to sulphate attack, freeze-thaw, alkali-silica reaction and other means. Cavitation damage occurs on concrete surface when discontinuity or irregularities is encountered in the path of high velocity water flow.

According to Ref. [16], cavitation resistance of the alkali-activated cement concrete structures working in the zones of wave-cut/break is higher than that of portland cement concretes. In high humidity service conditions, the alkalis that are present in the alkali-activated cement stone allow for self-healing of the zones of stress concentrations and strengthening of the alkaliactivated cement concrete due to "renewal" (re-start) of the processes of hydration and hardening resulting in densification of the concrete structure and filling of its defects (pores, etc.) with hydration products (Table 15).

\begin{tabular}{|c|c|c|c|c|c|c|}
\hline \multirow[t]{3}{*}{ Curing/exposure conditions } & \multicolumn{3}{|c|}{ Alkali activated slag cement concrete } & \multicolumn{3}{|c|}{ Portland cement concrete } \\
\hline & \multicolumn{2}{|c|}{ Strength (MPa) } & \multirow{2}{*}{$\begin{array}{l}\text { Wear } \\
\left(\mathrm{cm}^{3} / \mathrm{h}\right)\end{array}$} & \multicolumn{2}{|c|}{ Strength (MPa) } & \multirow{2}{*}{$\begin{array}{l}\text { Wear } \\
-\left(\mathrm{cm}^{3} / \mathrm{h}\right)\end{array}$} \\
\hline & Compressive & $\begin{array}{l}\text { Tensile } \\
\text { bending }\end{array}$ & & Compressive & $\begin{array}{l}\text { Tensile } \\
\text { bending }\end{array}$ & \\
\hline \multirow{2}{*}{$\begin{array}{l}28 \text { days in normal conditions } \\
\text { (after steam curing) }\end{array}$} & 50.00 & 4.00 & 8.27 & 40.50 & 4.40 & 6.36 \\
\hline & 39.00 & 4.00 & 9.11 & 30.00 & 2.80 & 12.25 \\
\hline \multirow[t]{2}{*}{180 days in sweet water } & 53.50 & 6.14 & 6.21 & 43.00 & 5.20 & 6.21 \\
\hline & 41.50 & 5.40 & 7.38 & 32.40 & 3.30 & 10.36 \\
\hline \multirow[t]{2}{*}{180 days in sea water } & 55.60 & 8.24 & 5.42 & 41.50 & 4.13 & 6.43 \\
\hline & 45.00 & 7.23 & 5.96 & 28.60 & 3.18 & 11.34 \\
\hline
\end{tabular}

Note: Fine aggregate alkali-activated slag cement concrete (soluble sodium carbonate as alkaline activator).

Table 15. Wear caused by cavitation (cavitation resistance) of alkali-activated cement and portland cement concretes vs. curing/exposure conditions.

Thus, durability of the alkali-activated cement concretes, assessed in terms of endurance and wear resistance, is comparable and even exceeds that of portland cement concretes, especially in unfavourable (extremely severe) service conditions.

\subsection{Corrosion due to alkali-aggregate reaction (AAR-induced corrosion)}

One of the reasons associated with concrete durability is an alkali-aggregate reaction (AAR), which is a reaction between alkali of cement and alkali-susceptible aggregate. Rate of this 
reaction is determined by a type and quantity of alkalis, and type and content of reactive silica. In case of the alkali-activated cements, which contain alkalis in much higher contents compared to that of portland cements, this problem is important. For this, a number of research projects have been performed [26-28], which showed a possibility to keep the AAR under control with a so called "positive" effect. The results of study showed that it could be possible due to introduction into the cement or concrete composition of aluminate-containing additives, in the presence of which a destructive ("negative") process of corrosion converts into a constructive ("positive") one. This is attributed to binding of the corrosion products with the formation of the alkali-activated aluminosilicate hydrates according to the following scheme:

$$
\mathrm{Na}_{2} \mathrm{O} \bullet \mathrm{SiO}_{2} \bullet \mathrm{nH}_{2} \mathrm{O}+\mathrm{Al}_{2} \mathrm{O}_{3} \bullet \mathrm{SiO}_{2}->\mathrm{Na}_{2} \mathrm{O} \bullet \mathrm{Al}_{2} \mathrm{O}_{3}{ }^{\circ} 2 \mathrm{SiO}_{2} \bullet \mathrm{nH}_{2} \mathrm{O}
$$

The resulted compound forms a dense and strong cage (shell) around the aggregate thus preventing corrosion processes.

This conclusion coincides well with the results of the following experiment: the metakaolin additive in a quantity of $15 \%$ was introduced into the cement composition to minimize influence of the destructive processes in the interfacial transition zone.

The influence of additive type on expansion deformations is shown in Figure 5. As follows from Figure 5a, non-admissible high expansion deformations were observed in the concretes made from portland cement with the increased content of $\mathrm{Na}_{2} \mathrm{O}(1.3 \%)$ and from the alkaliactivated portland cement with the $\mathrm{Na}_{2} \mathrm{O}$ content of $2.5 \%$ in which andesite rock was used as coarse aggregate.
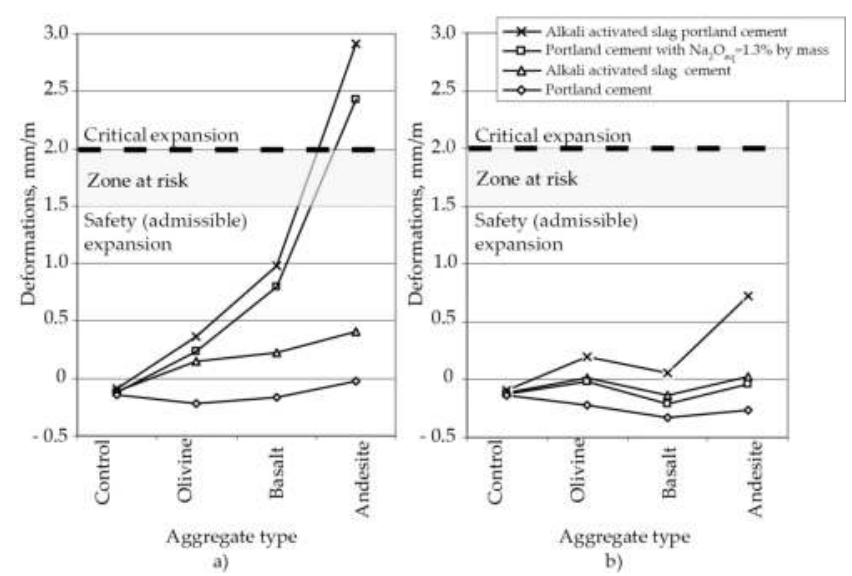

Figure 5. Influence of aggregate type (olivine, basalt, andesite) and metakaolin additive on deformations of the concrete specimens: (a) without additive; (b) with the metakaolin additive (15\%); curing conditions -28 days of continuous steam curing at $\mathrm{T}=343 \mathrm{~K}$ and relative humidity $=100 \%$. 
Corrosion products in the interfacial transition zone and microcracks occurring in the aggregates of the concretes made using portland cement with the increased contents of $\mathrm{Na}_{2} \mathrm{O}$ and the alkali-activated slag portland cement are clearly seen in the electron microscope images. On the contrary, the use of the alkali-activated cements is not at any risk, and the interfacial transition zone "cement stone-alkali-susceptible aggregate" remained clear.

The introduction of the additive will allow to shift all concrete compositions not only from the zone of not allowable critical expansion and deterioration, but also from the zone of risk, not depending upon a cement type and aggregate type. The interfacial transition zone in this case is clear and without sign of corrosion. This may be attributed to the fact that conditions required for synthesis of alkaline zeolite-like aluminosilicate hydrates of the general formula $\mathrm{Na}_{2} \mathrm{O} \cdot \mathrm{Al}_{2} \mathrm{O}_{3} \cdot \mathrm{mSiO}_{2} \cdot \mathrm{nH}_{2} \mathrm{O}$ are created in the interfacial transition zone in the presence of reactive $\mathrm{Al}_{2} \mathrm{O}_{3}$ in a strongly alkaline medium, that is, the alkali starts to bind very quickly.

The alkali-activated cement stone has low deformation expansions even without the metakaolin additive. This may be attributed to high contents of reactive $\mathrm{Al}_{2} \mathrm{O}_{3}$ in the glass phase of the slag.

\section{Practical experience}

Theoretical data in combination with those obtained experimentally that have been collected by a scientific school headed by Professor Viktor Glukhovsky (currently is headed by Professor Pavel Krivenko) allowed as early as in 1958 to launch first pilot scale production of the alkaliactivated cement concrete products and to continue in 1962 with industrial-scale production of a number of concrete small-size building elements and structures.

The majority of alkali-activated slag cement concrete structures manufactured in 1960s was intended for hydro-engineering, in particular, marine engineering application that work in extreme service conditions (corrosive exposure of running waters, alternate freezing-thawing in winter, wetting and drying in summer, etc).

Regular continuous observations over the alkali-activated cement concrete small-size building elements and structures showed their higher performance properties compared to those of portland cement concretes as reference (Tables 16-18).

From these tables, performance properties of these concretes tended to increase during the whole period under review. This may be attributed to permanent deepening of the hydration processes, resulted in the formation of low basic calcium silicate hydrates and zeolite-like water-resistant final products of the alkaline as well as mixed (alkaline- alkali earth) composition. Low water permeability and high resistance of the alkali-activated cement concretes in aggressive environments can be explained by nature of their hydration products [17,29].

The results of chemical analysis showed that quantities of free (unbound) alkalis in the alkaliactivated cement concretes varied from 0.3 to $0.5 \%$. A pH-index inside the alkali-activated slag cement concretes was 12.7-12.9. This is an evidence of presence in these concretes of an alkaline 
medium which is required for the further flow of processes of hardening in the alkali-activated cements as well as for passivation of reinforcement steel. The alkalis are released in very small quantities. This is attributed to the increased density of the alkali-activated slag cement concrete, closed porosity and nature of hydration products.

\begin{tabular}{|c|c|c|c|c|c|c|}
\hline \multirow{2}{*}{$\begin{array}{l}\text { Structure (small-size building } \\
\text { element) }\end{array}$} & \multirow{2}{*}{$\begin{array}{l}\text { Mnfg } \\
\text { year }\end{array}$} & \multirow[t]{2}{*}{ Aggregate } & \multirow{2}{*}{$\begin{array}{l}\text { Alkaline } \\
\text { activator }\end{array}$} & \multirow{2}{*}{$\begin{array}{l}\text { Initial } \\
\text { strength } \\
\text { (MPa) }\end{array}$} & \multicolumn{2}{|c|}{ Test results (1973) } \\
\hline & & & & & $\begin{array}{l}\text { Freeze/thaw } \\
\text { resistance } \\
\text { (cycles) }\end{array}$ & $\begin{array}{l}\text { Strength } \\
\text { (MPa) }\end{array}$ \\
\hline $\begin{array}{l}\text { Cast-in-situ facing concrete } \\
\text { covering of main irrigation } \\
\text { channel (under water level) }\end{array}$ & 1962 & Heavy sandy loam & $\mathrm{Na}_{2} \mathrm{CO}_{3}$ & 15 & 900 & 42.60 \\
\hline The same, above water & 1962 & The same & $\mathrm{Na}_{2} \mathrm{CO}_{3}$ & 15 & 900 & 40.00 \\
\hline $\begin{array}{l}\text { Pre-stressed precast concrete } \\
\text { elements of irrigation system }\end{array}$ & 1964 & $\begin{array}{l}\text { Sea sand (fineness } \\
\text { modulus }=0.9 \ldots 1.1 \text { ) }\end{array}$ & $\mathrm{Na}_{2} \mathrm{CO}_{3}$ & 25 & 700 & 59.50 \\
\hline Precast concrete piles & 1964 & The same & $\mathrm{Na}_{2} \mathrm{CO}_{3}$ & 30 & 600 & 71.80 \\
\hline Cast-in-situ road pavement & 1965 & The same & $\mathrm{Na}_{2} \mathrm{CO}_{3}$ & 10 & 250 & 47.60 \\
\hline $\begin{array}{l}\text { Cast-in-situ breakwater massive } \\
\text { elements }\end{array}$ & 1965 & The same & $\mathrm{Na}_{2} \mathrm{CO}_{3}$ & 30 & 570 & 62.00 \\
\hline Prefabricated pavement slabs & 1965 & The same & $\mathrm{Na}_{2} \mathrm{CO}_{3}$ & 25 & 437 & 67.00 \\
\hline Centrifuged pipes $(d=100 \mathrm{~mm})$ & 1966 & $\begin{array}{l}\text { River sand (fineness } \\
\text { modulus }=1.65 \text { ) }\end{array}$ & $\mathrm{Na}_{2} \mathrm{CO}_{3}$ & 30 & - & 83.00 \\
\hline Large-size wall blocks & 1967 & Waste of shell rock & $\mathrm{Na}_{2} \mathrm{CO}_{3}$ & 10 & 300 & 31.30 \\
\hline
\end{tabular}

Table 16. Performance properties of alkali-activated cement concretes after long-term service in various exposure conditions.

\begin{tabular}{|c|c|c|c|c|c|}
\hline \multirow[t]{2}{*}{ Type of concrete } & \multirow{2}{*}{$\begin{array}{l}\text { Design compressive } \\
\text { strength (MPa) }\end{array}$} & \multicolumn{4}{|c|}{ Compressive strength (MPa) after exposure in sea water during } \\
\hline & & 1 year & 3 years & 5 years & 7 years \\
\hline \multicolumn{6}{|c|}{ Slabs of embankment } \\
\hline $\begin{array}{l}\text { Alkali activated slag cement } \\
\text { (alkaline activator-sodium } \\
\text { carbonate) }\end{array}$ & 40.0 & 40.0 & 47.8 & 53.8 & 57.0 \\
\hline Portland cement & 39.0 & 39.0 & 38.5 & Destroyed & \\
\hline \multicolumn{6}{|c|}{ Slabs immersed in sea water (under layer of biomass) } \\
\hline $\begin{array}{l}\text { Alkali activated slag cement } \\
\text { (alkaline activator-sodium } \\
\text { carbonate) }\end{array}$ & 40.0 & 40.0 & 59.6 & 60.1 & 61.4 \\
\hline Portland cement & 39.0 & 39.0 & 47.6 & 51.6 & 50.0 \\
\hline
\end{tabular}

Table 17. Performance properties of alkali-activated cement slag concretes after service in sea water (Black Sea, Odessa, Ukraine). 
Large-scale production of the alkali-activated cement concretes in the USSR showed their high efficiency. Cost savings (30-40\%) were achieved due to the use of by-products and waste materials, as well as longer span of service life, especially in extreme conditions. These alkaliactivated materials are in line with principles of global sustainable development: near-zero carbon dioxide emissions, low-energy consumption (no high temperature processes), preservation of natural resources, etc.

\begin{tabular}{|c|c|c|c|}
\hline \multirow[t]{2}{*}{ Structure (small-size building element) } & \multirow{2}{*}{$\begin{array}{l}\text { Age of concrete } \\
\text { (years) }\end{array}$} & \multicolumn{2}{|c|}{ Water permeability (MPa) } \\
\hline & & $\begin{array}{l}\text { Initial (1 month } \\
\text { after placing) }\end{array}$ & After service \\
\hline $\begin{array}{l}\text { Cast-in-situ concrete facing of main irrigation channel (under } \\
\text { water level) }\end{array}$ & 12 & 0.6 & 1.8 \\
\hline $\begin{array}{l}\text { Chutes, pre-stressed, precast } \\
\text { Pre-stressed precast concrete elements of irrigation system }\end{array}$ & 9 & 1.0 & 2.0 \\
\hline $\begin{array}{l}\text { Massive (large-size) water breaks, precast blocks } \\
\text { Cast-in-situ breakwater massive elements }\end{array}$ & 8 & 0.8 & 2.0 \\
\hline Slabs in service under layer of biomass & 8 & 0.8 & 2.0 \\
\hline The same, isolated from biomass & 8 & 0.8 & 2.0 \\
\hline
\end{tabular}

Table 18. Water permeability of alkali-activated slag cement concretes after long-term service.

\section{Conclusions}

Numerous studies held on alkali-activated cement concretes supported by test results showed that they could work successfully with high efficiency in various structures withstanding extreme service conditions (alternate freezing-thawing, aggressive environments, dynamic and static loads, etc.). In their performance properties (freeze-thaw resistance, water permeability, corrosion resistance, etc.), the alkali-activated cement concretes are superior to portland cement ones and can be recommended for marine engineering applications, especially for so called "responsible use" structures that are in service in extreme weather conditions and under exposure of alternating loads and aggressive environments.

\section{Author details}

Pavel V. Krivenko ${ }^{1 *}$, Hai Lin $\mathrm{Cao}^{2}$, Lu Qian Weng ${ }^{2}$ and Oleg N. Petropavlovskii ${ }^{1}$

*Address all correspondence to: pavlo.kryvenko@gmail.com

1 V.D. Glukhovsky Scientific Research Institute for Binders and Materials, Kiev National University of Construction and Architecture, Kiev, Ukraine

2 Advanced Materials Research Institute, Shenzhen Academy of Aerospace Technology, Shenzhen, P.R. China 


\section{References}

[1] Verbetsky GP. Strength and Durability of Concrete in Water. Moscow: Stroyizdat; 1976. $127 \mathrm{p}$.

[2] Dvorkin LY, Dvorkin OL, Dorofeev VS, Mishutin AV. Concretes for Hydroengineering Application and Roads. Odessa: LLC Zovnishreklamservis; 2012. 216 p.

[3] Glukhovsky VD. Soil Silicates. Kiev: Gosstroyizdat; 1959. 154 p.

[4] Krivenko PV. Alkaline cements. In: Proceedings of the First International Conference on Alkaline Cements and Concretes. Kiev: VIPOL Stock Company; 1994. p. 11-129.

[5] Krivenko P. Alkaline cements, concretes and structures: 50 years of theory and practice. In: Proceedings of the International Conference on Alkali-Activated Materials, Research, Production and Utilization. Prague: Agentura Action M; 2007. p. 313-332.

[6] Glukhovsky VD. Soil Silicate Building products and Constructions. Kiev: Budivelnyk; 1967. $155 \mathrm{p}$.

[7] Glukhovsky VD. Selected Works. Kiev: Budivelnik; 1992. 208 p.

[8] Krivenko P. Alkaline cements: terminology, classification, aspects of durability. In: Proceedings of the $10^{\text {th }}$ Int. Congress on the Chemistry of Cements (10 ${ }^{\text {th }}$ ICCC). Goeteborg: Amarkai AB and Congrex; 1997. p. 4 iv 046

[9] National Standard of Ukraine DSTU B V.2.7-181:2009 “Cements, Alkaline”. Kiev: Ministry of Regional Development and Building; 2009.

[10] Krivenko PV. Synthesis of cementitious materials in a system $\mathrm{R}_{2} \mathrm{O}-\mathrm{Al}_{2} \mathrm{O}_{3}-\mathrm{SiO}_{2}-\mathrm{H}_{2} \mathrm{O}$ with required properties [DSc thesis]. Kiev: Kiev Polytechnical Institute; 1986.

[11] Krivenko PV, Runova RF, Sanitskiy MA, Rudenko II. Alkaline Cements. Kiev: Osnova LLC; 2015. 448 p.

[12] National Standard of Ukraine DSTU BV.2.7-25:2011 “Heavyweight Concretes, Alkaline". Kiev: Ministry of Regional Development and Building; 2009.

[13] Glukhovsky VD, editor. Alkaline and Alkaline-Alkali Earth Hydraulic Binders and Concretes. Kiev: Vyscha Shkola Publish; 1979. 232 p.

[14] Glukhovsky VD, editor. Fine Aggregate Slag Alkali Activated Cement Concretes. Kiev: Vyscha Shkola Publish; 1981. 224 p.

[15] Krivenko PV, Pushkarjeva EK. Durability of Slag Alkaline Cement Concrete. Kiev: Budivelnyk; 1993. 223 p.

[16] Goncharov V. Study of resistance of fine aggregate alkaline cement concretes in antisliding structures and coastal defense structures [PhD thesis]. Kiev: Kiev Civil Engineering Institute; 1973. 
[17] Krivenko PV. Special Slag Alkaline Cements. Kiev: Budivelnyk; 1992. 192 p.

[18] Mironenko A. Resistance of slag alkaline cement concretes in solutions of mineral salts [PhD Thesis]. Kiev: Kiev Civil Engineering Institute; 1985.

[19] Goncharov N. Corrosion resistance of slag alkaline binders and concretes in organic aggressive environments [PhD Thesis]. Kiev: Kiev Civil Engineering Institute; 1984.

[20] Shi C, Krivenko P, Roy D. Alkali-Activated Cements and Concretes. London and New York: CRC Press; 2006. 376 p.

[21] Muhammedgaleeva S. Study of properties and manufacturing technology of alkali activated slag cements in the conditions of the Far North [PhD Thesis]. Kiev: Kiev Civil Engineering Institute; 1976.

[22] Krivenko P, Cao H, Petropavlovskiy O, Weng L, Pushkar V. Effect of technology of manufacturing the alkali activated cement concretes porous structure and frost resistance. In: Proceedings of the Int. Conference on Non-traditional Cement and Concrete V. Brno: NOVPRESS s.r.o.; 2014. p. 119-122.

[23] Krivenko P, Cao HL, Weng LQ. Manufacture of alkali activated slag cement concretes for marine structures in the PR of China. Journal "Budivnytstvo Ukrainy". 2013; 4: 2932.

[24] Solodky SY. A slag alkaline cement concrete for construction of rigid road pavements [PhD Thesis]. Kiev: Kiev Civil Engineering Institute; 1991.

[25] Fujii T, Zako M. Fracture Mechanics of Composite Materials. Moscow: Mir; 1982. 232 p.

[26] Krivenko PV, et al. A role of metakaolin additive on structure formation in the contact zone "cement-alkali-susceptible aggregate". In: Proceedings Int. Symp. on Nontraditional Cement and Concrete II. Brno: Brno University of Technology; 2005. p. 8395.

[27] Krivenko PV, Gelevera AG, Kavalerova ES. Comparative study of alkali-aggregate reaction in the OPC and alkaline OPC concrete. In: Proceedings 16. Int. Baustofftagung 2, Weimar; 2006. p. 0389-0398.

[28] Krivenko P, et al. Mechanism of preventing the alkali-aggregate reaction in alkali activated cement concretes. Cement and Concrete Composites. 2014;45:157-165.

[29] Butt YM, Rashkovich LN. Hardening of Binders at Elevated Temperatures. Moscow: Stroyizdat Publish; 1965. 240 p. 
